6

\section{A Lewisian History of Philosophy}

\author{
ROBERT PASNAU
}

Great philosophers force us to rethink not only the future of philosophy, but also its past. Or, as Nietzsche more graudly puts it: "Every great human being exerts a retroactive force: for his sake al of history is put on the scale again, aud a thousand secrets of the past crawl out of their hiding places -into his sunshine." In what follows, wielding the bright light of Lewisian metaphysics, I try to draw into the open some less well-known moments from the history of philosophy. My concern will not be to interpret David Lewis himself, or to reflect on how he may have been influenced by the history of philosophy. Instead, reversing the usual direction of argument, I want to appropriate Lewis's ideas, roughly conceived, as a vehicle for coming to a clearer understanding of some episodes in the history of the discipline. ${ }^{2}$

\subsection{Properties}

Any class of things, be it ever so gerrymandered and miscellaneous and indescribable in thought and language, and be it ever so superfluous in characterising the world. is nevertheless a property. So there are properties in immense abundance... Because properties are so abundant, they are undiscriminating. Any two things share infinitely many properties, and fail to share infinitely many others. That is so whether the two things are perfect duplicates or utterly dissimilar. Thus properties do nothing to capture facts of resemblance. ${ }^{3}$

For most of the recorded history of philosophy it has been assumed that an adequate account of language and thought would require postulating abstracta of one sort or another including. iuter alia, Platonic Forms, Aristotelian forms, Stoic lekta, and Avicennian inteutious. To be sure, there were exceptions. After all, one could hardly engage the subject in any serious way without at least pausing to wonder whether it is necessary for the philosopher to traffic in such obscurities. Even so, the massive influence of Plato and especially Aristotle on late antiquity and beyond guaranteed that one or another kind of Realism would dominate philosophy for many a century.

One particularly well-developed line of resistance appears in the later Middle Ages, and was given its most influential statement by William Ockham in the early fourteenth century. ${ }^{4}$ Ockham's

A Companion to David Lewis, First Edition. Edited by Barry Loewer and Jonathan Schaffer,

(C) 2015 John Wiley \& Sons, Inc. Published 2015 by John Wiley \& Sons, Inc. nather like Darwin's biology stands to natural theology no It is not that Ockham - the "venerable inceptor" of nominalon - pun an en but rather that he gave such prominent and articulate voice to the alternative the sions could no longer responsibly carry on as they had before. After Ockham, scholastic philosophers sions could no longer responsibly carry on asinalist camps, and some universities even endowed dual sell-consciously divided into reald have its champion. ${ }^{5}$

作 language. His predecessors had gener-

For Ockham, nominalism was first and foremost a theory of language. Hs predecesire some appea ally assumed that an adequate analysis of subject-predicate statements would require some appea to a common nature or universal. Ockham, in contrast, argued that language could be explaine entirely in terms of concrete particulars: token sentences - spoken, written, or mental - that signify entirely in terms of concrete parts. His general strategy for linguistic analysis is to treat an affirmative individual things in the world. sentence as true if and only if its subject and pr-called identity theory of predication, we can say that posit for") the same thing or thing

(1) Socrates is an animal

comes out true iff "Socrates" and "animal" both supposit, in the context of the senteuce, for the same individual. Similarly,

(2) All human beings are animals

certain individual things and "animals" supposits comes out true for all of those same things (it may also supposit for out, among the subject-term picks out all the human beings, and the predicate term other things, all the human heings. Of course, the theory requires a story abut " context of a given senteuce, and modified by syncategorematic terms like "all," comes to have a context of a given sere giew, is that we certaiu supposition. But the great ad singular affirmative need uot postulate an ontology of prope
propositions like (1) above, he writes:

[DIt is not required that the subject and pedicate be in reality in the [1]t is not regat it really inhere in the subject, or that the predicate be united to that subject in extra-mental subject or that treally infere in the subject, or that the subject and predicate supposit for the same thing. ${ }^{6}$ What abont sentences where the property itself seems to fignre as a referent? Even here, Ockham is unrelenting. He holds, for instance, that an abstract term like "anim but simply to particular auimals - different ones depending on the coutext in which the term appear

'Animality' does not stand for an accident of an animal, nor for one of an animal's parts, nor for any whole

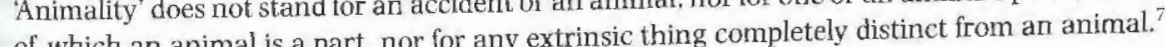

This forces Ockham to accept as trne sentences like "Socrates is animality." Better this, though, than admit a world of indefinitely many entities corresponding to all the nominalizations that language could construct from predicates:

This is the source of many errors in philosophy: to hold that for a distinct word there always corresponds This is the source of many errors in philosophy. to hom that for a dignified match the distinctions among names or significant words. ${ }^{8}$ 
The cure for this tendency is Ockham's Razor.

Beyond the semantic difficulties that arise from foregoing properties, there are questions abou how to explain the similarity between things. It is natural to suppose that Socrates and Fido are similar because they share, among other things, the property of animality. Without any such property, Ockham must either deny the similarity story turns on treating similarity as primitive. Some things just are similar to each other, whereas others are not. Where one finds similarity, there is nltimately nothing more to say than that This is like that. The resemblance is ineliminable, and not further analyzable. Accordingly, "God canno make two white things without their being similar, because the similarity is the two white thing themselves."

There is much here for the Lewisian to approve of. The easy allure of abstracta has been resisted, replaced by subtle linguistic analysis and the strategic recourse to brute simplicity. But Ockham' nominalism is perhaps too extreme to be defensible. He wants to fashion a semantic theory that can be run not only without universals, Platonic or immanent, but also without individual properties or tropes. He furthermore explicitly excludes any prospect of treating properties as classes of individuals, when he remarks above that animality is not "any whole of which an animal is a part." This precludes the Lewisian strategy of treating animality as the collection of all animals. The costs of this approach are steep, inasmnch as Ockham must struggle mightily to account for many ordinary sentences in natural language.

Ockham's nominalism lies at one extreme on the historical continnum of opinion regarding properties. Subsequent opinion, when it did not reject his views out of hand, tended to solten the auster lines of his approach in one way or another, sometimes by invoking a category of entities known modes, which were understood as something less than real properties but somehow somethin beyond just substances. ${ }^{10}$ Indeed even Ockham himself departed from a perfectly nominalistic rejection of all properties, inasmuch as he recognized certain kinds of individual properties (or tropes) in the category of Quality. This, however, raises a new question: how to distinguish between those descriptions of the world that are merely artificial, and those that capture its trne nature.

\subsection{Carving at the Joint}

The realism that recognizes a nontrivial enterprise of discovering truth about the world needs the raditional realism that recognizes objective sameness and difference joints in the world discriminatory classifications not of our own making

The initial philosophical impulse, scarcely distinguishable from the original scientific impulse, was to discover the fnndamental entities that give rise to the world of appearances. The crude efforts of Thales and his contemporaries are familiar enough, as are the more sophisticated efforts of Democritus, who combined anti-realism at the level of appearances with realism at the microscopic level: "By convention sweet and by convention bitter, by convention hot, by convention cold, by convention color; but in reality atoms and void." 12 This sort of reductionism seems to have struck Plato as being too crude even to deserve any mention in his dialogues. It is to Plato that we owe the memorable image of "cutting up each kind according to its species along its natural joints, and trying not to splinter any part, as a bad butcher might do." ${ }^{13}$ But Plato is talking about conceptual analysis rather than physical reduction, toward which, as we will see, he was generally hostile.

It was perhaps Aristotle's single most important achievement to fashion a via media between the radically opposed programs of Platonic idealism and Presocratic reductionism. The side of Aristotle that leans toward Platonism - the theory of forms - is naturally the most discnssed part of the theory, but from a historical point of view Aristotle's more reductive side is also extremely important. In his work On Generation and Corruption, Aristotle embraces - as the best available scientific account - the doctrine of the four elements and their four associated qualities. The elements are Earth, Air, Fire and Water - capitalized, because, for instance, elemental Earth is not any kind of ordinary earth, bu , becal in such earthly stuff arises out of a mixture from each of these four elements. The elements, however, are not actually basic to the scheme. The truly basic explanatory principles are the qualities - Hot. Cold, Wet, and Dry - where again the capitalization stresses that these are theoretical postulate rather than the ordinary sensihle qualities. Each element carries with it two such basic qualities, ${ }^{1}$ and it is the mixture of these qualities, in varying proportions, that gives rise to the qualitative variation among observable phenomena.

Medieval Aristotelians referred to these four qnalities as the primary qualities, and pnt them at the center of their natural philosophy. According to Albert the Great, "the primary qualities of tangible things are the cause of all the other sensible qualities," by which he means the so-called secondary qualities, such as color and flavor. Thomas Aquinas says that these fonr primary qualities are "the cause of generation and corruption and alteration in all other bodies," which is to say that they explain all the most fundamental events in nature ${ }^{15} \mathrm{By}$ the seventeenth century, this scholastic terminology was deeply entrenched in the philosophical curriculum, and could be used to plot its downfall. Robert Boyle, tnrning such Aristotelian vocabulary against itself, contrasts "the primary and mechanical affections, ... motion, figure, and disposition of parts" with "those more secondary affections of bodies ... which are wont to be called sensible qnalities." John Locke, a few years later. would make famous our now-canonical distinction between the primary qualities (by which of course he means size shape, and so forth) and the secondary qualities (color, heat, etc.) ${ }^{16}$

For a few shining decades, it really seemed as if everything in nature could be explained in terms of geometric-kinetic properties. To be sure, the most carefnl philosophers of the period did not want to introduce this sort of "mechanical" philosophy as a new philosophical dogma. René Descartes, the most careful of them all, asked the readers of one of his early, unpublished treatises to "allow your thoughts to wander beyond this world to view another world - a wholly new one which I shall bring into being before vour mind in imaginary spaces."17 What he proceeds to imagine is a world without forms and qualities, a world with only solid bodies - res extensa -infinitely divisible and put in motion according to the laws of nature familiar from this world. Is that imaginary world in fact our world Descartes, in this early work, was uot willing to say so, bnt he did say that, for all we can tell, it might be our world, inasmnch as a world like that, consisting only of particles in motion, could give rise to all the phenomena around us.

Right here, at the start of the "modern" era, we have the Lewisian strategy for thinking about the foundations of reality: admit that the issues are contingent, articulate what looks to be the most elegant theory compatible with the empirical evidence; defend the tenability of that theory against conceptual, philosophical objections. What happened to this Lewisian program in the seventeenth century is that, by the close of the century, it was apparent to well-informed observers that Newtonian forces had spoiled the dreams of a purely mechanical theory. As the young Newtonian John Keill remarked in 1702, "although the mechanical philosophy is today celebrated in name, and in our era its practitioners have attained fame, nevertheless in most of the writings of the physicists one can find hardly anything mechanical beyond the name itself." ${ }^{18}$ For the 300 years since then, the metaphysical foundations of science have become steadily more obscure.

Let us then set aside those foundations, and focus on macro-level, ordinary perceptible objects. Here again, from the beginnings of philosophy, one finds doubt about how best to proceed. The same impulses that led Democritus to anti-realism regarding sensible qnalities led him to nihilism regarding composition. Plato's disinterest in physical reduction is of a piece with his broader disinterest in 
the world of sights and sounds. ${ }^{19}$ Again one finds in Aristotle a compromise attempt to save commonsense ontology by deploying forms immanently and inseparably within material objects, as a principle of unity. For as long as Aristotelianism held sway - which is to say for most of the history of philosophy, until around 350 years ago - it was generally supposed that philosophy had a wellunderstood principle of composition, at least for the paradigm case of living things. (The situation for artifacts was always less clear.) On this approach it is a determinate fact whether, at a given instant, a particular bit of stuff is informed by an animal's substantial form or soul. Accordingly, there is nothing vague about when a substance comes into and goes out of existence, or where its spatial boundaries lie.

Once the Aristotelian consensus collapsed, in the middle of the seventeenth century, the philosophical understanding of substance collapsed with it. Spinoza opts for monism; Hobbes allows unrestricted composition; Leibniz thinks substantial forms must be retained; Descartes seems to have no theory at all..$^{20}$ Among the empiricists, the characteristic strategy was to eschew metaphysical speculation in favor of an analysis of our pragmatic interests, as reflected in language and ideas, which are presumed to be divorced from the true metaphysical reality. Thus Locke insists that although be believes in substance as the unifying entity beneath sensible qualities, he thinks this we "have no distinct idea of at all "21 We have, he thinks, no idea of what it is in genera to be a substance, nor do we have any idea of what particular snbstances are, such as a piece of gold or a horse. Still, we cannot escape talking about such things, and so in place of the idea of the rea essence that would define a particular substance, we frame the idea of a nominal essence. Thus the way we talk has only a partial connection with the way things are: "the species of things to us are nothing but the ranking them under distinct names according to the complex ideas in us, and not according to precise, distinct, real essences in them."22

The era from Descartes to Hume liberated philosophy from the arcana of Aristotelian metaphysics. In so doing, these figures were forced to take seriously the prospect that metaphysics might part ways with common sense. Ultimately, the baroque complexities of scholastic thought served at the behest of a descriptive metaphysics that aimed to do as much justice as possible to our pre-theoretical worldview. But once philosophers tried doing without that marvelous all-purpose device that is the Aristotelian form, they found common sense impossible to save. Of necessity, metaphysics had to become revisionary, or had to be abandoned altogether. Metaphysicians today, Lewisian or not, face much the same choices, pulled in different directions by the comfort of common sense, the allnre of speculative metaphysics, and the worry that such speculation is idle.

\subsection{Persistence}

A persisting thing is like a parade; first one part of it shows up, and then another. (Except that most persisting things are much more continuous than most parades.) The only trouble with this hypothesis is that very many philosophers reject it as counterintuitive, or revisionist, or downright crazy (except in the case of events or processes). It is a mystery why. ${ }^{2.3}$

Having slain the Minotaur, escaped the labyrinth, and returned triumphant to Athens, Theseus felt obliged to honor Apollo by sending a yearly tribute to the sanctuary on Delos. This reqnired a ship. and it seemed fitting to use the very same ship that Theseus had used in escaping from Crete. According to Plutarch, that same ship was preserved for centuries in the Athenian harbor, and sent out every year on its religious mission, even down through the time of Aristotle. Of course, a ship that old, moored continuously at sea, required constant maintenance, and it can safely be assumed that. old, moored continuously at sea, required constant maintenance, and it can safely
by Aristotle's time, none of the original wood was extant. You know the question.
Puzzlement over persistence goes back to the beginnings of philosophy, and gave rise to protracted debates between those who were skeptical about whether anything persists through change, and those who championed various metaphysical solutions to the problem of change. The sorts of solutions available of course depended on the metaphysical resources that one or another school of thought allowed itself. The Stoics, whose materialism allowed room for an ontology of substances and qnalities, individuated bodies both at a time and over time by relying on qualitative sameness and difference. This led them to embrace the identity of indiscernibles. ${ }^{24}$ Most, however, assumed that qualitative sameness was quite unsuited to account for identity over time, given the obvious fact about change. Indeed, some did not think that the diachronic identity of substances even allowed for the identity of qualities over time. According to the Asharite school of Islamic theology, only atom inhere in those atoms, tive character, exist only for an instant, and so mnst be created anew by God at every successive moment. ${ }^{25}$ Philosophers in the Latin-Christian tradition were equally quick to develop such surprising views. Peter Abelard and the other Nominales of the twelfth century, for instance, commonly endorsed the thesis that "Nothing grows," on the grounds that growth entails a kind of change that is incompatible with sameness. ${ }^{26}$

It might be supposed that Aristotelians are immune to puzzles of persistence, in virtue of having available not only accidental forms, which may come and go, but also the substantial form - for living things, the soul - that individuates substances over time. This may be true for Aristotle himself and for early scholastic Aristotelians such as Thomas Aquinas. Indeed, some scholastics introduced multiple substantial forms within living substances, one in virtue of which it is a body, and one or more others in virtue of which it is an animal or a hnman being. This allows a single substance to mave nested sets of essential properties: to be rational in virtue of its rational soul for instance, and to be extended in virtue of its bodily form. It is not that there are two things here, a body and a human being, but that there is one complex thing, which in different respects has different essential featnres, features that might come apart insofar as its different substantial forms might come apart. ${ }^{27}$ Again it can start to feel as if we can use forms to do anything in metaphysics.

Beginning in the fourteenth century, however, a certain sort of skepticism arose about whether forms could help at all in solving puzzles of persistence. These worries arose within the later medieval nominalist tradition, and grew out of two principles that Ockham himself had clearly articulated:

Part-Whole Identity. A whole is nothing other than its parts.

The No-Transfer Principle. Forms cannot transfer from subject to subject.

Ockham takes the first principle to entail mereological essentialism, that no whole can survive the loss or gain of any of its parts:

It is impossible for any one whole thing in its own right, distinct from other things, to exist in reality unles each part of it exists in reality... Hence if just one part does not exist in reality, then neither does the whole exist. ${ }^{28}$

This all by itself blocks the simple Aristotelian appeal to substantial form, because even if the substantial form endures through snch change, the whole substance cannot endure. But the No-Transfer Principle makes things even worse, because it entails that not even the substantial form can persis through change to a thing's parts. Change at the material level, on this account, forces change at the formal level. Hylomorphism accordingly turns out to be completely worthless in accounting for diachronic identity 29

Part-Whole Identity has a long history in these discussions. going back to the twellth-century Nominales and to the Hellenistic debates between the Stoics and the Academic skeptics. ${ }^{30}$ For skeptics 
regarding persistence, the focus has tended not to be on the Lewisian problem of qualitative change, but rather on the problem of material change - that is, on the gain or loss of integral parts rather than on the gain or loss of properties. This reflects the widespread notion that what endures through time is not the thick substance that is the thing together stance, the thing itself, the bare cat shorn of its accidental features. So even though the principle of non-contradiction was generally felt to be binding on all parties, it takes the right sort of contradictory assertions to trigger a violation. That cat can be friendly today and feisty tomorrow, because those are advening states of its soul, not strictly parts of the cat. But if the cat is feisty because it lost a piece of its tail, then that makes for metaphysical trouble. And of course it was common knowledge, then as much as now, that material substances are constantly gaining and losing parts.

Skepticism regarding persistence is a tenable view only when it comes with some sort of further story about why we talk as if things persist. The most famous such account is Locke's, who takes the usual nominalist line regarding material substances, that they endure only for as long as their parts endure: "if one of these atoms be taken away, or one new one added, it is no longer the same mass or the same body." ${ }^{31}$ But just as Locke distingnishes between real and nominal essences, so he distinguishes between the strict metaphysical story abont substantial persistence and the ideas that figure in how we talk about persistence:

It is not therefore unity of substance that comprehends all sorts of identity, or will determine it in every case. But to conceive and judge of it aright, we must consider what idea the word it is applied to stands for: it being one thing to be the same substance, another the same man, and a third the same person. Person, Man and Substance are three names standing for three different ideas; for ing to that name, such must be the identity. ${ }^{32}$ (1975, Essay II.27.7)

It is usually supposed that in passages such as this Locke really means to be talking about true metaphysical identity, and accordingly it is supposed that we must wait until Hume to get a clear accoun of the difference between an "uninterrupted and invariable object" and a "succession of relate objects." ${ }^{33}$ But in fact Hume's skeptical line about diachronic identity differs from Locke's mat its emphasis. And Locke himself is simply repackaging mialerial from nominalist discussions All the way bat ro make sense, in much the All the way back in the fourteenth century, John Buridan had attempted to make sense, in much the same way, of our casual attitudes toward identity. First, there is stric identity:

There are three ways in which we are accustomed to say that one thing is numerically the same as another The first way is by being totally (totaliter) the same - namely becaus this is that and the is nother belonging to the whole of this that does not belong to the whe the of cal sameness in the most proper cense. According to his wal it her I was yesterday for yesterday the and serisolved, and something else that yesterday did not belong to my whole which later, by nutrition, was made to belong to my whole

Buridan accepts part-whole identity, and accordingly he thinks that numerical sameness is properly had only if a thing retains all and only the same parts. The most that can be said about a hnman being then, is that it is partially the same - which is just to say that part of it, the human soul, endures:

In a second way, however, one thing is said to be partially the same as another - namely, because this is part of that...And in this way a human being remains the same through the totality of his life because the soul remains totally the same, and the soul is the principal - indeed the very most principal - part. A horse, however, does not remain the same in this way, and indeed neither does the human body
Buridan also accepts the no-transfer principle. Because the human soul is more than just the form of the body - because it is immaterial - it endures through change to that underlying body. In the case of all other material substances, however, their forms depend on their bodies; the ongoing sameness of a horse's soul, for instance, depends on the horse's bodily sameness. Inasmuch as the horse's body is constantly changing, one needs to understand the horse's diachronic identity in a still looser sense, like the identity of a river over time:

But in a still third way, less properly, one thing is said to be numerically the same as another according to the continuity of distinct parts, one in succession after another. In this way the Seine is said to be the same river after a thousand years, although properly speaking nothing is now a part of the Seine that was part of it ten years ago. For thus the ocean is said to be perpetual, as is this earthly world, and a horse is the same through its whole life and likewise so is the human body. ${ }^{34}$

Such continuity of course does not make for identity in any strict sense, but it explains the sense in which we can truly speak of changing things being the same through time. Locke, more than 300 years later, embraces all of this, and adds to it the brilliant and wholly original suggestion that we form the idea of personal identity in still another way, in terms of psychological continuity.

Lewisians will doubtless be heartened by the good sense displayed in these various strategies for retreating from strict identity. Still, they may wonder whether there is room for just one more tiny step, that of calling into question whether anything at all endures through time, all of its parts intact. and considering the possibility that instead things might perdure, by being composed of a series of ever-changing temporal parts. The question was indeed asked, in the context of debates over entic successiva. The idea that there is a divide between two sorts of entities, permanent and successive, goes back to Aristotle. As one example of the familiar principle that being is spoken of in many ways, he offers this: "we say it is day or it is the games, because one thing after another is always coming into existence." The canonical examples are motion and time, about which Aristotle remarks: "time has parts, some of which have been, others of which are going to be, but no part of it is." ${ }^{.35}$ In later discnssions, permanent entities are understood either as those that are capable of wholly existing al at once, or as entities that wholly endure through time. Snccessive entities fail both of these tests: there can, for instance, be neither time nor motion at an instant, and the whole of time and motion does not endure through its whole existence.

Historically, one finds philosophers of every persuasion embracing successive entities as gennine things over and above permanent entities. The idea appears in Aquinas, Arnauld, Augustine, and Avicenna - to canvass just the start of the alphabet. With the concept of an ens successivum in mind, it is natural to wonder whether there might be more such things than initially appears, and even whether everything might turn out to be an ens successivum, on the grounds that nothing endures through time. Nicole Oresme, in the mid-fourteenth century, expressly argued for this possibility, and in particular for the possibility that a rational animal might be created in this way by God, temporal part after temporal part: "such an aggregate from all these would be a human being, a successive substance, of which nothing that existed in a given part of time existed in a subsequent part." Albert of Saxony, building on Oresme's discussion a few years later, argued that this is not just metaphysically but also epistemically possible: that for all we know this is in fact how things are. Still, he add that he will follow "the general custom" and treat material substances as permanent entities. ${ }^{36}$

So close. But yet so far, and that largely because, for all of the recorded history of philosophy, a peculiar idée fixe has held sway, the idea of an enduring material substratum of change. ${ }^{37}$ Opinion about the character of this substratum has varied widely. For Democritus and the Epicureans, and again for Gassendi in the seventeenth century, it was atoms that endured beneath all material change. For Aristotelians, it was unformed, "prime" matter. For Descartes it was res extensa, infinitely divisible 
but essentially extended stuff. Despite dramatic differences in detail, it is hard to find anyone in the history books who did not accept that there is some sort of stuff that endures through all natural change, usually stuff that was thought to be itself, intrinsically changeless. Hence, although substances may come and go, it is never the case that a complete gulf separates what was and what will be. What will be is always composed of some stable ingredients that already were. Hence even when Oresme and Albert of Saxony imagined a successive human being, what they imagined is that God Oress and might naturally might miraculously do things in this way. They were not imaging Nature, or so almost everyone has supposed, for all of the history of philosophy, works by recycling the same enduring ingredients, over and over.

\subsection{Causality}

The world has its laws of nature, its chances and causal relationships; and yet - perhaps! - all there is to the world is its point-by-point distribution of local qualitative character. ${ }^{38}$

It would be natural to suppose that, up until the time of Hume, philosophers generally and uncritically accepted the notion of causality in something like our modern sense. In fact, nothing could be farther from the case. The range of pre-modern views is bewildering in the extreme, and be fom their dogmatic slumbers, but to Hune's controus obscnrity. If Hume's show off one way in which causality might be analyzed without nystery and obscnrity. If Hume's story was hard to believe, at least it posed a salutary challenge: tell me what you think causality is, in a way that is sufficiently credible that I might reasonably rely on that story in framing beliefs about the future.

For the Presocratic atomists, causality was a relatively straightforward affair, a matter of atoms in motion producing motion in other atoms through contact. To be sure, even this very simple picture in motion producing motion in of allied raises all sorts of hard questions, many of which would become prominent once atomism and allosophical views returned to center stage in the seventeenth century. But the main course of philosophical mockery of reductive mechanistic explanation, most famously in the Phaedo:

When I was a young man I was wonderfully keen on that wisdom which they call natural science, for I When I was a young man I was wonderfully keen on that wisdom which they call natural science, for thought it splendid to know the causes of everything, why it comes to be, why it perishes and why it exists. I was often changing my mind in the investigation, in the first instance, of questions such as these: Are living creatures nurtured when heat and cold produce a kind of putrefaction, as some say? Do we thin with our blood, or air, or fire, or none of these, and does the brain provide our senses of hearing and sight and smell?... As I investigated how these things perish and what happens to things in the sky and on the earth, finally I became convinced that I have no natural aptitude at all for that kind of investigation, and of this I will give you sufficient proof. This investigation made me quite blind even to those things which I and others thought that I clearly knew before, so that I unlearned what I thought I knew before ..

Plato's target is the sort of causal explanations found among Presocratic authors - in effect, the Plato's target is the sort of causal explanations found an perfectly familiar business of explaining natural phenomena in terms of their basic physical constituents. What such putative explanations distracted him from was something he "knew before," which of course turns out to be the Forms of sensible things. Plato goes on to admit that it may seem naive and foolish to think we can explain beautiful things by their sharing in the Beautiful itself (100d). But the culminating moment of the Phaedo is its argument that we can turn our grasp of individual But the culminating moment of the Phaedo is its argument istinct Forms, and thereby reach new and substantive conclusions, such as that the soul by its very nature must be immortal.
Although there are vast and contentious questions here for scholars to ponder, what is most salient from a Lewisian perspective is that Plato turns his back on the project of giving explanations that run entirely in terms of local matters of fact. Somehow, particular facts are tied together by a network of necessary connections with higher-order Objects, and these connections are fundamental both to how things are and to how we know them.

When we turn to Aristotle, again we find him seeking a via media that, in the present context, amounts to wanting it both ways. Famously distinguishing between four different senses of cause or explanation, Aristotle wants to leave room for the causal role both of local matters of fact and of necessary conhections between those facts. The forms become immanent, and are now conceived of as powers. Powers on their own are not necessarily or inevitably actualized; in many cases they amount to a disposition: the disposition to behave in a certain way, or to enter into a certain state, once the appropriate conditions are realized. In the simplest sort of case, "whenever something capable of acting and something capable of being acted upon are together, what is potential becomes actual." ${ }^{40}$ It is often said that efficient causation corresponds to what we now mean by causality, but this is misleading. The efficient cause is simply the agent, and an agent acts (paradigmatically) by bringing its form or power or disposition to bear upon an object that is suited to receive its impression. Efficient causality, then, like material and final causality, depends fundamentally on formal causality. Indeed, Aristotle's ethics, his physics, and his psychology all crucially depend on a theory of forms as immanent powers. Even more fundamentally, his ontology of substance depends on the notion of a governing form or essence that, when realized in an appropriate matter, gives rise to the various defining features of that substance. Again one sees the extraordinary explanatory power of forms, a power that will strike the Aristotelian as a strong recommendation, but may look to the uninitiated as more like theft than good honest work.

Such forms, if they are to be of any value at all, must play an explanatory role in connecting local matters of fact: why certain complex structures persist througb time as unified individuals; why certain individuals characteristically behave in certain ways; why certain sorts of behavior is invariably and predictably followed by other sorts of behaviors. The tendency among modern Aristotelians, from Leibniz forward, is to think of these forms in highly abstract, functional terms, as a metaphysical postulate that floats free of the concrete physical story told by science. This was not, however, the later medieval tendency. When scholastic authors defended Aristotle against more reductive approaches, they treated forms, in effect, as a physical hypothesis, an essential ingredient in a complete scientific account of observable phenomena. Phenomena ranging from substantial unity to gravity, and from moral conduct to digestion, were all thought to require forms of one sort or another as an ineliminable part of the causal story. As criticism of the Aristotelian approach gained increasing traction, in the sixteenth and seventeenth century, the tendency of its scholastic defenders was not to treat forms as a strictly metaphysical postulate, as Leibniz later would, but to offer them instead as part of a full scientific account of natural phenomena. Here, the Lewisian might say, we have an honest attempt to make good on the Aristotelian hypothesis. Honest but, nnfortunately, empirically discredited ${ }^{41}$

But if we must give up forms, then what? One solution is to give up entirely on powers and dispositions. This is what Descartes comes close to doing, at least if one sets aside the special case of mind "there are no powers in stones and plants that are so mysterions... that they cannot be explained.. from principles that are known to all and admitted by all, namely the shape, size, position, and motion of particles of matter." ${ }^{2}$ Another way forward was pioneered in England by Robert Boyle and then made famous by John Locke, whose theory of secondary qnalities as "nothing in the objects themselves but powers" 43 derives largely from Boyle. Unlike Descartes, Boyle does not seek to get rid of forms and powers. His most important philosophical work introduces as its topic "the nature and origin of qualities and forms, the knowledge of which either makes or supposes the most fundamenta 
and useful part of natural philosophy." Forms, far from being rejected, remain at the center of Boyle's thought, but they do so merely as explanatory principles that can ultimately be analyzed in terms of the mechanical pbilosophy. The dissolvability of gold in aqua regis is "not in the gold any thing distinct from its peculiar texture"; the poisonousness of the peas "is really nothing distinct from the glass itself." More precisely, the poison is nothing beyond the ground glass contained in the peas, together with various anatomical facts about the creature for whom it is poisonous. In general, powers are thing agen that has the power. Thus, "we must consider each body not barely as it is in itself an entire and distinct portion of matter, but as it is a part of the universe..."."

Our long Platonic detour, hijacked right at the start by the Aristotelians, has now come to an end leaving us back sqnarely on the reductive course with which we began among the Presocratics. Still, ducible causal agents, we still have unreduced mechanical impulses - bodies moving other bodies. Locke, even while he accepted snch causation, despaired of understanding how it happens: interactions between bodies are "as obscure and unconceivable as how our minds move or stop our bodie by thought." ${ }^{45}$ Such worries all by themselves might have produced Hume's doubts over necessary connections, but there is another strand of thought that needs accounting for. the theological strand mind of God This is, most lamously, Nicholas Malebranche's position, whose work was indeed recommended by Hume as preparation for reading the Treatise of Human Nature. Some 65 years before Hume, Malebranche had already argued that "when we examine our idea of all finite minds, we do not see any necessar connection between their will and the motion of any body whatsoever. On the contrary, we see that there is none and that there can be none." The same conclusion holds for any two created entities. But Malebre nection, but that it involves a different sort of necessary connection, one between God and creatures: "the mind perceives a necessary connection only between the will of an infinitely perfect being and its effects." ${ }^{46}$

Much the same idea occurred centuries earlier, in Islamic thought. According to al-Ghazali, writing at the end of the eleventh century,

The connection between what is habitually believed to be the cause and what is believed to be the effect is not necessary, according to us. Rather, take any two things. Neither is the same as the other, the affirmation of one does not include the affirmation of the other, and the negation of one does not include the negation of the other. The existence of one does not necessitate the existence of the other, nor does the nunexistence of one necessitate the nonexistence of the other:

Again the point is not to deny necessary connections, but to locate them between God and creatures and so to identify God as the only true cause. When combined with the earlier-mentioned Asharite denial of enduring properties, the result is a view on which the only things in the material realm that endure are atoms, and on which causation is simply God's creating a new state of the world at each instant. $\mathrm{Can}$ this be squared with experience? Here too Islamic occasionalism anticipates at each instant. Can thi Hume's later remark that all we actually observe is one event's coming after another. Al-Ghazali, for instance, remarks of his opponent's theory of causality that "their only proof is the observation of the occnrrence of the burning upon contact with the fire. But observation proves that the occurrence took place upon contact with fire, not that the occurrence took place by virtue of contact with fire." 48

For the occasionalist, the denial of necessary connections, combined with the thesis of empirical equivalence, point toward the rejection of any sort of creaturely causation. The nature of Hnme's own conclusion is less clear. At a minimum, he wants to establish that the idea of a causal power uniting distinct objects can be grounded neither in relations of ideas nor matters of fact, which is to say that this idea has no legitimate snpport. The only idea we can legitimately have of causation is the idea of constant conjunction, whether that be understood as mere regnlarity or in counterfactual terms ${ }^{49}$ Arguably Hume wants the stronger conclusion that causation just is constant conjunction. but scholars disagree over whether Hume actually intends to go that far..$^{50}$

These are radical conclusions, however exactly they are understood, but they are grounded in familiar, almost nncontroversial premises. The denial of necessary connections between distinct individuals can be found not just in Hume and his occasionalist predecessors, but also in a relatively orthodox Aristotelian account of causality such as Ockham's. It is indeed a fairly obvious point tha there are no logically necessary connections between distinct individuals. It is equally easy to find precedents for the empirical side of Hume's attack on causality: that observation shows nothing about what causes what. Again, one finds this idea in Ockham, among others. ${ }^{51}$ Why then do occasionalists and Humeans derive their startling conclusions from such commonplace principles? The short answer is that more commonsensical views turn out, on reflection, to look deeply unsatisfactory. The Aristotelian's appeal to intrinsic, irreducible powers seems to locative a primitive mystery at the very foundations of the natural world. Powers give rise to connections that are necessary not logically but only in some weaker metaphysical sense: it is of the nature of a thing of a certain kind to act in just such a way, in just such circumstances. Why is this? It just is. As this sort of thinking came to look less credible in the seventeenth century, an alternative account of necessary connections emerged, in terms of natural laws. Francis Bacon dismissively remarks that "forms are fictions of the human soul - unless we are allowed to say that forms are the laws of action." ${ }^{2}$ Descartes even while he rejected Aristotelian powers, eagerly embraced the idea of "certain laws that God has so established in nature, and of which he has implanted such notions in our souls, that after adequate reflection on them we cannot doubt that they are exactly observed in everything that exists or occurs in the world." ${ }^{53}$ Isaac Newton was wise enough not to encumber his beautiful physics with metaphysical speculation abont what a law might be, but that does not make the philosophical problem go away. Absent some further philosophical account, it is easy to think that the appeal to laws of nature is just a way to get divine influence in by the back door - that we have returned to occasionalism, albeit in a localized, regulated way..$^{54}$

Whether or not Hume himself believed that causation jnst is conjunction, the difficulties with all rivals views has made the idea look increasingly attractive in modern times. Although a satisfactory analysis in counterfactual terms has proved elusive, it is not clear that historical reflection reveals better options.

\subsection{Modality}

I believe that things could have been different in countless ways; I believe permissible paraphrases of what I believe; taking the paraphrase at its face value. I therefore believe in the existence of entities that might be called 'ways things could have been'. I prefer to call them 'possible worlds', 5

Though historical generalizations are always hazardous, it seems safe to say that no one before David Lewis attempted to account for modality in terms of Lewisian modal realism has no exact historical precedent, there is of course considerable precedent for the idea that possible worlds can somehow contribute to an understanding of modality. We have seen the idea in Descartes already, with his talk of another, imaginary, world where mechanism reigns. Still earlier examples of the usage abound, which is not at all surprising, given how natural it is to speak of "worlds" in describing alternative possible states of affairs. ${ }^{56}$ 
The most famous case is Leibniz, according to whom "there is an infinity of possible universes in God's ideas" - though he immediately adds that "there cannot exist more than one of them." ${ }^{57}$ There cannot exist more than one, because by definition a world is "the entire sequence and the entire collection of all existing things., ${ }^{58}$ So only one world exists, but still "there is an infinity" of possible worlds, apparently in the sense that "God's ideas" represent infinitely many unrealized worlds. Interestingly, Leibniz denies the possibility of trans-world individuals, and so understands modality in terms of counterpart theory, remarking that when one considers one of the infinity of possible Sextuses, one is not considering "entirely the same Sextus" but rather "a near-Sextus." ${ }^{59}$ Leibniz" reasons for this view are idiosyncratic, however, arising not because of how he conceives of possible worlds, but because of his commitment to "superessentialism," which entails that Sextus would not be Sextus if other things had happened to him. In general, "because of the interconnection of things, the whole universe with all its parts would be quite different and would have been different from the beginning, if the least thing in it had happened differently than it did." 60

How do such appeals to ersatz possible worlds help explain modality? Let us go back much earlier to some of the first-known accounts of modal language. Diodorus Cronus, circa $300 \mathrm{BCE}$, is said to have offered the following account:

The possible is that which either is or will be [true]; the impossible that which is false and will not be true; the necessary that which is true and will not be false; the non-necessary that which either is false now or will be false. ${ }^{63}$

Boethius, our sonrce for this report. immediately complains that this is a hopeless account: it has the absurd consequence that someone who dies at sea could not have died on land. Why would Diodorus have offered something so evidently unsatisfactory? Surely it was not that he failed to recognize more expansive modal notions of the kind that Boethius takes for granted. Our information is so limited that we can only speculate; Arthur Prior has suggested we think of Diodorus as an ancient Quine offering "some 'harmless' senses that might be attached to modal words." ${ }^{62}$ The Lewisian might indeed recognize Diodorns as an ancient master, unwilling to give up modal talk entirely, but resolved to find some solid footing on which to place it, and hence settling for an account that accords only partially with our pretheoretical intuitions. Rather than take the brash Lewisian step of making possibilia real, Diodorus settles for limiting possibilia to the concrete domain of what is or will occur. (Even this, however, will be less than ideal as solid footing, unless Diodorus is prepared to secure the reality of future events by endorsing eternalism. Until very recently, however, philosophers seem to have almost universally taken for granted that only the present is real. ${ }^{63}$ )

One finds at least traces of these Diodoran modalities throughout ancient and medieval thought - not because of Diodorus' influence, but because ideas of this kind can be found slightly earlier in Greek thought, in Aristotle. He writes in the Metaphysics, for instance, that "it cannot be true to say this is capable of being but will not be,." 64 On the usual understanding of how possibility relates to necessity, this entails that what exists alwavs exists necessarily, and in fact Aristotle elsewhere says that "a thing is eternal if it is by necessity; and if it is eternal, it is by necessity." ${ }^{\circ 5}$ These would seem to be clear statements of what Jaakko Hintikka has labeled a "statistical" model of modality, which analyzes modality in terms of frequency of actnal occurrence. ${ }^{66}$ It is contentious, however, whether Aristotle actually believes that modality can be analyzed in these terms, or even whether he accepts these statistical principles at face value. In his famous discussion of tomorrow's sea-battle, he remarks that "it is possible for this cloak to be cut up, and yet it will not be cut up but will wear out first." This obviously violates the Diodoran rule for possibility, along just the lines that Boethius had complained of. So that rule is surely not Aristotle's. What Aristotle instead seems to have endorsed is a statistical rule for modality in case of things that exist eternally. ${ }^{68}$ This is exactly what he says, after all, in the above-quoted passage concerning necessity. And we can understand the bolder passage concerning possibility as limited to cases where a thing is allowed an infinite run of existence. Such a rule is particularly important for Aristotle because he in fact believed that our world, along with the species of things within it, is eternal, both in the past and, apparently, in the future. This led him to some surprising ideas about human history. Since he was committed to the view that whatever human beings could do is something that in fact they had done in the past, he remarks for instance that over the many distant centuries "every art and philosophy has probably often been developed as far as possible and then perished." ${ }^{\prime 69}$ This looks weird, until one begins to reflect on the implications of saying that human history is literally infinite. And once one begins to reflect on the character of eternity, it might even begin to look as if the actual history of this world provides a sufficient gronnd for possibilia.

Yet, even if we can make good sense of Aristotle's statistical rule, it seems unlikely that anyone understood it as an account of the gronnds of modality. Thomas Aquinas would later be quite clear about this. He dismisses the Diodoran modalities as "a posteriori" in the classical sense - that is, as capturing not the nature of modality but at best one if its consequences: "Something is necessary not because it always will be, but rather it always will be because it is necessary, and the same is clear in the other cases." Aquinas then offers his preferred view:

Others have distinguished these [modalities] better, in terms of the nature of things. On this account, that is said to be necessary whose nature is determined solely to existence; the impossible is determined solely to non-existence; and the possible is wholly determined neither way ... This is plainly Aristotle's view here. ${ }^{70}$

The suggestion is that what accounts for modality is not the fact of a thing's occurrence at other times, but the intrinsic nature of a thing. This is another way of making the sort of appeal to forms and powers we observed in the previous section: what a thing can do, and what it must do, are determined by the inner potentialities that determine the web of necessary connections between substances. Again, postulating forms is the easy road to philosophical explanation, and from Aristotle through the Middle Ages, this was the road more traveled. ${ }^{7}$

In the present context, however, it cannot be enough simply to appeal to the forms of actual substances, because this will not capture the full range of possibility, which presumably extends over various unrealized possibilities - natures that have never and will never be instantiated. Here the natural move for theists is to appeal to facts about the nature of possibilia as they are in the divine mind. This is a view that one finds running not only throngh medieval authors, but also into the seventeenth century and beyond. Descartes, for instance, holds that "the eternal truths are true or possible only because God knows them as true or possible. They are not known as true by God as if they are true independently of him." Descartes goes on to identify God's knowing and willing, and adds that "in willing something, he thereby knows it, and thereby alone snch a thing is true." ${ }^{72}$ This provokes, rather than settles, the familiar Euthyphro-like questions that plague theists: do necessary truths obtain becanse God wills them, or does God will them becanse they obtain? Aquinas is more clear about which side he takes: "God does something because he wills it; but he can do something not because he wills it, but because his nature is so."

With this we can return to Leibniz. Although he is fond of describing modality in terms of possible worlds, in fact it is the divine mind that gronnds modality. As we saw, the infinity of possible worlds exists only "in God's ideas." Leibniz is in fact quite explicit about what in fact grounds modal truths:

Without God there would be nothing real in possibles - not only nothing existent, but also nothing possible. For if there is reality in essences or possibles, or indeed in eternal truths, this reality must be grounded in something existent and actual, and consequently it must be grounded in the existence of the necessary being ... 
Whereas the Lewisian would force us to choose between admitting real and concerete possible world or else denying the Moorean fact of modal truths, the Leibnizian dilemma is either to deny moda truths or admit the existence of God..$^{75}$ For Leibniz. talk of possible worlds is simply a façon de parler, one that, at least for a modern reader threatens to obscure the ultimate theological foundations of one that,
modality.

What goes for form goes a fortiori for God - it makes metaphysics easy, perhaps all too easy. But the theologically-minded have not always supposed that the divine ideas are capable of grounding all modality. A particularly interesting case is John Duns Scotus. He accepts the usual view that one kind of modality is grounded in the powers of things, and another kind grounded in the divine ideas of non-actual things. But Scotus insists on a third kind of modality, for which he coined the term "l ic proposition are not incompatible. This idea itself is not new with Scotus. It is found quite expressly in Aquinas as well, who in turn traces the view back to Aristotle. ${ }^{76}$ What is interesting about Scotus discussion (although Aquinas suggests this view as well) is that logical possibility is grounded neither in the powers of actual things, nor in the divine ideas: Suppose, before the creation of the world, that there was not only no world but also, per impossibile, no God. Suppose that God then began on his own to exist and was capable of creating the world. Then, if there had been an intellect before the world, and that intellect had formed the proposition The world will exist, this proposition would have been possible, because the terms are not incompatible. This proposition would have been possible not on the basis of something in re possibili, or a corresponding active power. or because of God's potentiality, formally speaking, but because of the potentiality which was the nonincompatibility of the terms."

There is a sense, then, in which we can speak of possibility independently of the natures of what exists, and even independently of God's ideas of their natures.

This new level of modal theory immediately raises the question of what grounds this "nonincompatibility" of terms. The phrase itself, after all, seems to smuggle in modal content. Scotus offers an answer of sorts, in considering why a human exists is logically possible but a chimera exists is logically impossible:

The reason existence is not incompatible with human but it is incompatible with chimera is because this is this and that is that - and this holds no matter whose intellect conceives of them

Evidently, we have hit rock bottom in Scotus' account, with logical possibility turning out to be simply a brute metaphysical fact. ${ }^{78}$ One can see the appeal of invoking this further level of modality, but it has the effect of undermining any sense that modal facts have been explained. Lewisians might fee home satisfuction at this result but might also wonder whether a similar complaint can ultimately be made against even the most boldly realist conception of possible worlds.

\subsection{Conclusion}

When historians of philosophy tell us that we can learn from the past, they usually have in mind the prospect of dict exciting philosophical prospect in drom old philosopby paths. This can happen. Sometimes, however, the most valuable thing we gain from cld philosopby is a proper appreciation of just how few paths forward there are, and how deeply unsatisfactory they currently on - difficult, dim, and weird though they may be - are in fact the correct way forward. Or that at least that some of them are. Maybe.

\section{Acknowledgments}

Thanks for their considerable help to Dominic Bailey and Bradley Monton.

\section{Notes}

Nietzsche 2001. $\$ 34$

wn en philosophy, one should remember his remark apropos Leibniz's theory of possible worlds that "It would be nice to have the right sort of talent and training a propos leibniz's theory of possible worlds the "I wo to me that I do not" (1986. viii). This remark should in to join in the work of exegesis, but it is very chear the fact that Lewis's mother, Ewart Lewis, was a medieval historian.

3 Lewis 1983, reprinted in Lewis 1999, 12-13. Honoralo might also thin

Tor an

6 Sum aniversal case, see Summa logicae II.4. For an overSum 1999.

Summa logicae L6 (William Ockham 1974, 59)

( Summ Summulae physicorum 11.7 (William Adams (1987, I, 143-67).

ontological program, see Marilyn Adams (1987, I, 143-67). See Marilyn Adams (1987, I, 109-21).

9 Reportatio II.1 (William Ockham 13.

11 Lewis 1984, in Lewis 1999, 67

The best source for Democritus' texts is 'Taylor (1999), in which this fragment appears as n. 179

13 Plato 1997, Phaedrus 265e.

14 Air is Hot and Wet. With that hint, the reader will be able to figure out the rest of the combinations. See Aristotle 1984, Gen. et Cor. II.1-5, for the overall account.

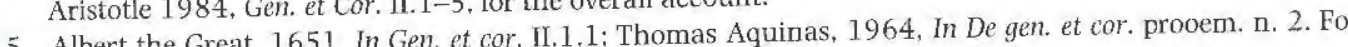
further discussion of medieval views, see Pasnau 2011, chapter 21.

fuld (1.98): Locke, Essay Concerning Human Understanding (1975, II.8).

(19.

18 Keill 1702 . 6 (Descar 1984 phsicam proface, $f$ ble

19 See Plot, Introductio ad veram physicam preface, the "the lovers of sights and sounds," as opposed to the see Plato's discussion at Republic $V 46 b$ (1997) of "he lite philosophers, who love Beauty itsell. For Denocritean nihilsm see Arist Democritus generates the visible and perceptiblebodies.... Bntanglem another, but does not really generate any single nature fic more things ever to become one" (Taylor 1999, n. 44a).

For the unfamiliar case of Hobbes, see De corpore 11.7 (1905): "a body is always the same, whether the parts of it be put together or dispersed; or whether it be congealed or dissolved." On Descartes' lack of theory. see Pasnau 2011, \$25.6.

21 Locke 1975, Essay II.23.2.

12 Locke 1975, Essu

3 Lewis 2002, 1. 
24 Debates over persistence are said to go back to Epicharmus in the filth century BCE, and make a brief appearance in Plato's Symposium $(1997,207 \mathrm{~d}-\mathrm{e})$. For the extensive Hellenistic debate, between the Academi skeptics and the Stoics, see Long and Sedley 1987, section 28. For the details of the Stoic approach, see Eric Lewis 1995

25 See Frank 1999 and Griffel 2009, 124-7.

26 See e.g. Arlig 2007 and King 2004.

27 See Pasnau 2011, \$25.3. Aquinas, it should be noted, opposed this sort of pluralism regarding substantial orm, on the grounds that such composition precludes substantial unity.

28 William Ockham, In Phys. IV.18.3 (1967-89, Opera phil. V.199).

29 For the details regarding Ockham's view, see Normore 2006 and Pasnau(2011, \$29.2).

30 See Barnes 1988

31 Locke 1975, Essay II.27.3.

32 Locke 1975, Essay II.27.7.

33 Hume 1978, Treatise I.4.6.

34 In Phys. I.10 (John Buridan 1964). Amazingly, this powerful and influential work has never been translated into English.

35 John Buridan 1964, Phys. III.6, 206a20-30; Phys. IV.10, 218a5-8.

36 For references and further discussion of this material, see Pasnau 2011, chapter 18.

37 See Pasnau 2011. \$2.1.

38 Lewis 1986,14

39 Plato 1997, Phaedo, 96a-c.

40 Aristotle 1984, Physics VIII.4, 255a34-b1.

41 On the later medieval tendency toward a concrete, physical conception of form see Pasnau 2011, passim.

42 Descartes 1984-91, Principles of Philosophy IV.187.

43 Locke 1975, Essay II.8.10.

43 Locke 1975, Essay I1.8.10. (Boyle 1979, 2, 24, 25, 26). For further discussion see Pasnau 2011, chapter Origin of Forms and Q

45 Locke 1975, Essay II.23.28.

46 Search after Truth VI.2.3 (Malebranche 1997, 448, 450). On the relationship between Hume and Malebranche, see e.g. McCracken 1983. Nadler 1996.

47 Incoherence of the Philosophers 17, in Khalidi 2005, 159. The view described here had been defended century earlier by the Asharite theologian al-Baqillani, among others, and it is not clear that al-Ghazal himself is committed to such an austere form of occasionalism. See Frank 1992; McGinnis 2006.

48 Incoherence of the Philosophers 17, in Khalidi 2005, 160. Malebranche makes similar remarks (see Nadle 1996, 462).

49 For both of these, in a single sentence, see Enquiry Concerning Human Understanding 7.2 (Hume 1902, 76 ).

50 Proponents of the so-called New Hume make an impressive case that Hume means to be making only an epistemological point about our access to necessary connections between distinct events, but there are also powerful arguments for ascribing to Hume the bolder view. See Read and Richman 2007.

11 See Marilyn Adams 1987, II, 741-58.

52 Bacon 2004, New Organon I.51.

52 Bacon 2004, New

54 For some remarks in this spirit, see Loewer (2012). For historical information, see Milton (1998), who remarks that "by the close of the seventeenth century, the idea that the main objective of natural philosophy lay in the discovery of the laws of nature had triumphed" (1.692).

55 Lewis 1973,84

56 For the premodern history of the concept, see Schmutz 2006.

57 Monadology par. 53 (Leibniz 1989, 220). See also Theodicy (Leibniz 1952) pars. 414-16 - where he speak of "worlds" (mondes) rather than "universes" (univers) - and see the useful summary in Parkinson 1995. $212-16$.

58 Theodicy par. 8 (Leibniz 1952), where uniqueness is expressly derived from the definition.

59 Theodicy par 414 (Leibniz 1952 .
60 To Arnauld, May 1986 (Leibniz 1989, 73). The exact details of Leibniz's views here have been the subjec of considerably scholarly debate; see e.g. Cover and Hawthorne 1990

Bethius. Second Commentary on the De interpretatione (1877-80, II.234)

62 Prior 1967, 16. Also on Diodorus see Denyer 1981.

62 Prior 1967 , John Wyclif, from the late fourteenth 3

64 Aristotle 1984. IX.4. 1047b4.

65 On Genertion also Nicomachean Ethics VI.3. $1139 \mathrm{~b} 22-24$.

1973 , chapter 5

(n) Bailey for initially calling my attention to this passage. See also Hintikka 1973, 100.

68 This is the suggestion in Hintikka 1973, 96. For the case of the cloak, see p. 100.

69 Metaphysics XII.8, 1074b10-11 (Aristotle 1984); see also Politics VII.10, 1329b25-35.

70 Thomas Aquinas 1962, Commentary on the De interpretatione I.14 n. 8.

71 There is a large and impressive literature on medieval modal theory. A good place to begin is Knuuttila 1993 and 2012.

72 To Mersenne, May 6, 1630 (Descartes 1984-91, ШाI:24).

73 Thomas Aquina 1947 , Suma theologine 1 a 25.5 ad 1 .

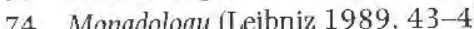

75 See Rort necessary being with personal attributes that make it appropriately described as God.

6.

77 John Duns Scotus 1950-, Ordinatio I.7.1 n. 27 (Opera IV.118); see also Ordinatio I.36 n. 61. Although John Duns Scotus $1950-$, Ordinatio Aquinas is not nearly so provocative, he might plausibly be rea oj massibility with the remark that, if all logiae 1a 25.3c (1947) when he introduces his own version of logical possibilty withes either circular or modality is grounded in God's power, then the doctrine of divine omnipotence becomes cither e.g. Wippel trivial. On the usual reading of Aquinas, however, he makes modality depen

78 John Duns Scotus 1950- Ordinatio L36n. 60. On logical possibitity as abrute fac 193. Scotus's interesting views about modality range over a host of other interesting issues, particularly 193. Scotus's inection of statistical modality, his denial of the necessity of the present, and his embrace of especially in accounting for free will. For an overview see Normore 2003.

\section{References}

Adams, M. (1987). William Ockham. Notre Dame: University of Notre Dame Press.

Adans, M. (1987). William Ockham. Notre Dame: Unist. New York: Oxford University Press.

Adams, R. (1994). Leibniz: determinist, theist, idealist. New York: Ox.

Aristote (1984). The complete works of Aristotle: the revised Oxford translation (2 vols.). Ed. J. Barnes.

Princeton, NJ: Princeton University Press.
Arlig. A. (2007). Abelard's assault on everyday objects. American Catholic Philosophical Quarterly, 81. 209-27.

Bacon F (2004). The instauratio magna part II: novum organum and associated texts (The Oxford Francis Bacon vol. 11). Ed. and trans. G. Rees \& M. Wakely. Oxford: Clarendon Press.

Barnes, J. (1988). Bits and pieces. In J. Barnes \& M. Mignucci (Eds.), Matter and metaphysics: fourth symposium hellenisticum, pp. 223-94. Naples: Bibliopolis.

Biard (2010) Nominalism in the later Middle Ages. In R. Pasnau (Ed.). Cambridge history of medieval philosophy, pp. 661-73. Cambridge: Cambridge University Press.

Boethius (1877-80). In librum Aristotelis peri hermeneias commentarii editio duplex. Ed. K. Meiser. Leipzig: Teubner. 
Boyle. R. (1979). The origin of forms and qualities according to the corpuscular philosophy. In M.A. Stewart (Ed.), Selected philosophical papers of Robert Boyle, pp. 1-96. Manchester: Manchester University Press.

Boyle, R. (1999-2000). The works of Robert Boyle (14 vols.). Ed. M. Hunter \& E.B. Davis. London: Pickering \& Chatto.

Cover, J.A. \& Hawthorne, J. (1990). Leibniz on superessentialism and world-bound individuals. Studia Leibnitiana, $22,175-83$.

Denyer, N.C. (1981). Time and modality in Diodorus Cronus. Theoria, 47, 31-53.

Descartes, R. (1984-91). The philosophical writings of Descartes (3 vols.). Trans. J. Cottingham. R. Stoothoff, D. Murdoch \& A. Kenny. Cambridge: Cambridge University Press.

Frank, R.M. (1992). Creation and the cosmic system: al-Ghazâli and Avicenna. Heidelberg: Carl Winter Universitätsverlag.

Frank, R.M. (1999). The Asharite ontology I: primary entities. Arabic Sciences and Philosophy, 9, 165231.

Griffel, E. (2009). Al-Ghazäli's philosophical theology. Oxford: Oxford University Press.

Hintikka, J. (1973). Time and necessity: studies in Aristotle's theory of modality. Oxford: Clarendon Press.

Hobbes, T. (1905). The metaphysical system of Hobbes. Ed. M.W. Calkins. Chicago: Open Court.

Hume, D. (1902). Enquiries concerning the human understanding and concerning the principles of morals. Ed. L.A. Selby-Bigge, 2nd ed. Oxford: Clarendon Press.

Hume, D. (1978). A treatise of human nature. Ed. P.H. Nidditch, 2nd ed. Oxford: Clarendon Press.

John Buridan. (1964). Quaestiones super octo physicorum. Frankfurt: Minerva. (Orig. work 1509.

John Duns Scotus (1950-). Opera omnia. Ed. C. Balić et al. Vatican: Scotistic Commission.

Kaufman, D. (2006). Locks, schlocks, and poisoned peas: Boyle on actual and dispositive qualities. Oxford Studies in Early Modern Philosophy, 3, 153-98.

Keill, J. (1702). Introductio ad veram physicam seu Iectiones physica habite in schola naturalis philosophiae Academiae Oxoniensis, quibus accedunt Christiani. Oxford.

Khalidi, M.A. (2005). Medieval Islamic philosophical writings. Cambridge: Cambridge University Press.

King, P. (2001). Duns Scotus on possibilities, powers, and the possible. In T. Buchheim, C.H. Kneepkens \& K. Lorenz (Eds.), Potentialität und Possibilität: Modalaussagen in der Geschichte der Metaphysik. pp. 175-99. Stuttgart: Frommann-Holzboog.

King, P. (2004). Metaphysics. In J. Brower \& K. Guilfoy (Eds.), The Cambridge companion to Abelard, pp. 65-125. Cambridge: Cambridge University Press.

Knuuttila, S. (1993). Modalities in medieval philosophy. London: Routledge.

Knuuttila, S. (1993). Modalities in medieval philosophy. London: Routledge.
Knuuttila, S. (2012). Modality. In J. Marenbon (Ed.). The Oxford handbook of medieval philosophy, pp. 312-41. Knuuttila, S. (2012). Modality. In J.
Oxford: Oxford University Press.

Leibniz, G.W. (1952). Theodicy. Ed. A. Farrer, trans. E.M. Huggard. New Haven, CT: Yale University Press. Leibniz, G.W. (1989), Philosophical essay. Trans. R. Ariew \& D. Garber. Indianapolis: Hackett.

Lewis, D. (1973). Counterfactuals. Oxford: Blackwell.

Lewis, D. (1983). New work for a theory of universals. Australasian Journal of Philosophy, 61, 343-77

Lewis, D. (1984). Putnam's paradox. Australasian Journal of Philosophy, 62, 221-36.

Lewis, D. (1986). On the plurality of worlds. Oxford: Blackwell.

Lewis, D. (1999). Papers in metaphysics and epistemology. Cambridge: Cambridge University Press.

Lewis, D. (2002). Tensing the copula. Mind, 111, 1-13.

Lewis. E. (1995). The Stoics on identity and individuation. Phronesis, 40, 89-108.

Loewer, B. (2012). Two accounts of laws and time. Philosophical Studies, 1601). 115-37.

Locke, J. (1975). An essay concerning human understanding. Ed. P.H. Nidditch. Oxford: Clarendon Press.

Locke, J. (1975). An essay concerning human understanding. Ed. P.H. Nidditch. Oxford: Clarendon Press.

McCracken, C.J. (1983). Malebranche and British philosophy. Oxford: Clarendon Press.

McGinnis, J. (2006). Occasionalism, natural causation and science in al-Ghazäli. In J.E. Montgomery (Ed.), Arabic theology, Arabic philosophy: from the many to the one: essays in celebration of Richard M. Frank, pp. 441-63. Leuven: Peeters.

Malebranche, N. (1997). The search after truth. Trans. T.M. Lennon \& P.J. Olscamp. Cambridge: Cambridge University Press.
Milton, J.R. (1998). Laws of nature. In D. Garber \& M. Ayers (Eds.), The Cambridge history of seventeenth-century philosophy, pp. 680-701. Cambridge: Cambridge University Press.

Nadler, S. (1996) "No necessary connection": the medieval roots of the occasionalist roots of Hume. Monist. $79,448-66$

Nietzsche, F. (2001). The gay science. Ed. B. Williams, trans. J. Nauckhoff. Cambridge: Cambridge University Press. Normore, C.G. (2003). Duns Scotus's modal theory. In T. Williams (Ed.). The Cambridge companion to Duns Scotus, pp. 129-60. Cambridge: Cambridge University Press.

Normore, C.G. (2006). Ockham's metaphysics of parts. Joumal of Philosophy, 103, 737-54.

Panaccio, C. (1999). Semantics and mentai language. In P.V. Spade (Ed.). The Cambridge companion to Ockham, pp. 53-73. Cambridge: Cambridge University Press.

Parkinson, G.H.R. (1995). Philosophy and logic. In N. Jolley (Ed.), The Cambridge companion to Leibniz. pp. 199-223. Cambridge: Cambridge University Press.

Pasnau, R. (2011). Metaphysical themes 1274-1671. Oxford: Clarendon Press.

Plato (1997). Complete works. Ed. J.M. Cooper. Indianapolis: Hackett.

Prior AN. (1967). Past, present, and future. Oxford. Clarendon Prett.

Read, R. \& Richman, K.A. (2007). The new Hume debate, rev. ed. London: Routledge.

Schmutz, J. (2006). Qui a inventé les mondes possibles? In J.-C. Bardout \& V. Jullien (Eds.). Les mondes possibles. pp. 9-45. Caen: Presses universitaires de Caen.

pp. 9-45. Caen: Presses universitaires de Caen.
Taylor, C.C.W. (1999). The atomists: Leucippus and Democritus. Toronto: University of Toronto Press.

Taylor, C.C.W. (1999). The atomists: Leucippus and Democritus. Toronto: University of Toro
Thomas Aquinas. (1947-8). Summa theologiae. Trans. L. Shapcote. New York: Benzinger.

Thomas Aquinas. (1962). Aristotle on interpretation: commentary by St. Thomas and Cajetan. Trans. J, Oesterle. Milwaukee: Marquette University Press.

Thomas Aquinas. (1964). Exposition of Aristotle's treatise on generation and corruption, Book I, cc. 1-5. Trans. P Conway \& R.F. Larcher. Colnmbus, OH: College of St. Mary of the Springs.

William Ockham. (1967-89). Opera philosophica et theological. St. Bonaventure, NY: Franciscan Institute.

Williarn Ockham. (1980). Ockham's theory of propositions. Trans. A. Freddoso \& H. Schuurman. Notre Dame. IN. Notre Dame University Press.

William Ockham. (1974). Ockham's theory of terms. Trans. M. Loux. Notre Dame, IN: Notre Dame University Press.

Wippel, J.E. (1981). The reality of nonexisting possibles according to Thomas Aquinas, Henry of Ghent, and Godfrey of Fontaines. Review of Metaphysics, 33, 729-58.

Zedler. B.H. (1976). Why are the possibles possible? New Scholasticism, 50, 504-21. 